WE have previously described inhibition of the synthesis of three acute-phase in flam $m$ atory cytokines in human and rat macrophages by acetate esters of rooperol, a dicatechol of plant origin. Analysing the mechanism of anticytokine activity of rooperol, we com pared levels of TNF $\alpha, \mathrm{IL}-1 \beta$ and IL-6 $\mathrm{m}$ RNAs in the human promonocytic $U 937$ cell line pretreated with phorbol myristate acetate (PMA) and incubated with rooperol tetraacetate (RTA) alone or in combination with LPS $(500 \mathrm{ng} / \mathrm{ml})$. It was found that $10 \mu \mathrm{M}$ RTA decreased the levels of cytokine mRNAs both in the presence and absence of LPS, suggesting pretranslational inhibition of cytokine synthesis. Electrophoretic mobility shift analysis (EMSA) showed that RTA may influence cytokin e $m$ RNA expression by decreasin $g$ the binding activity of transcription factors NF- $k B$ and AP-1.

Key words: U937 cells, Cytokine mRNA, Transcription factors, Rooperol tetraacetate

\section{Rooperol tetraacetate decreases cytokine mRNA levels and binding capacity of transcription factors in U937 cells}

\author{
A. Guzdek, ${ }^{1}$ H. Rokita, ${ }^{1}$ J. Cichy, ${ }^{1}$ A. C. Allison ${ }^{2}$ \\ and $A$. Koj ${ }^{1, C A}$
}

${ }^{1}$ Institute of Molecular Biology, Jagiellonian University, Al. Mickiewicza 3, 31-120 Kraków, Poland; '2DAWA Inc., Belmont, CA 94002, USA

\author{
${ }^{\mathrm{CA}}$ Corresponding author \\ Fax: (+48) 126336907 \\ Email: KOJ@mol.uj.edu.pl
}

\section{Introduction}

Macrophages, ubiquitous in the body, have the potential to produce several cytokines involved in inflammation, such as TNF $\alpha$, IL-1 $\beta$ and IL-6. ${ }^{1-5}$ Induced synthesis of these cytokines involves multiple cell signalling pathways and can be regulated at the level of gene transcription, mRNA stability and translation, or cytokine precursor processing and secretion. ${ }^{4,5}$ Overproduction of cytokines is believed to play a role in the pathogenesis of a wide range of disorders, such as septic shock, rheumatoid arthritis and asthma. ${ }^{6-9}$ Compounds which suppress cytokine production may have beneficial effects in the treatment of such diseases. The list of anti-inflammatory drugs affecting cytokine production is growing steadily and involves glucocorticoids, some antioxidants, ${ }^{6}$ bicyclic imidazoles, ${ }^{10}$ piperazine derivatives ${ }^{11}$ teni$\mathrm{dap}^{7,8}$ and many others. We have recently described inhibition of the TNF $\alpha$, IL-1 $\beta$ and IL-6 (at the protein level) in human and rat alveolar macrophages, human blood monocytes and human promonocytic cell line U937 by a plant dicatechol, rooperol, and its acetate esters. ${ }^{12}$ Rooperol derived from the plant Hypoxis rooperi is a potent inhibitor of 5 tipoxygenase, but in concentrations up to $10 \mu \mathrm{M}$ has no activity against either isoform of cyclooxygenase. ${ }^{13}$ This suggests that the drug might be therapeutically useful in disorders when it is desirable to inhibit the production of leukotrienes but not prostaglandins, such as asthma and inflammatory bowel disease. Evidence is accumulating that pro-inflammatory cytokines also contribute to the pathogenesis of these as well as other inflammatory disorders, so that it would be desirable to inhibit their production as well. Although rooperol exhibit antioxidative properties, ${ }^{13}$ and suppresses NO production by rat macrophages ${ }^{12}$ and murine endothelial cells, ${ }^{14}$ (overproduction of NO by inducible NO synthase may contribute to the pathogenesis of asthma ${ }^{9}$ ), the mechanism of its anticytokine activity requires elucidation. The study now reported is an analysis of the mechanism by which rooperol may suppress the production of pro-inflammatory cytokines. We describe the effect of rooperol te traacetate on the TNF $\alpha$, IL-1 $\beta$ and IL-6 mRNAs, as well as DNAbinding activity of two transcription factors in U937 cells exposed to rooperol in the presence and absence of bacterial endotoxin.

\section{Materials and Methods}

\section{Reagents}

RPMI medium, fetal bovine serum (FBS) and antibiotics-antimycotics were purchased from Gibco Life Technologies Inc. (Grand Island, NY); $\left[\alpha-{ }_{-3}^{32} \mathrm{P}\right] \mathrm{dCTP}$ and $\left[\gamma-{ }^{32}\right.$ P]ATP were obtained from Amersham International (Amersham, UK). Oligonucleotide probes were synthesized by Dr.A. Okruszek, Macromolecular Research Centre, Polish Academy of Sciences, Lodź, Poland. All other reagents were from Sigma (St Louis, MO, USA). Endotox in (LPS, lipopolysaccharide from Escherichia coli 026:B6, Sigma, St Louis, MO) was dissolved in sterile phosphate-buffered saline (PBS) at 
the concentration of $1 \mathrm{mg} / \mathrm{ml}$. Rooperol ((E)-1,5-bis $\left(3^{\prime}, 4^{\prime}\right.$-dihydroxyphenyl) pent 4 -en-1-yne $)$ te traacetate (RTA) was dissolved in DMSO as described previously $^{12}$ to obtain a stock solution $(100 \mathrm{mM})$, and was further diluted in 10\%bovine serum albumin in PBS.

\section{Cell culture}

U937 cells were grown at $37^{\circ} \mathrm{C}$ in $75-\mathrm{cm}^{2}$ flasks containing RPMI supplemented with 8\% FBS and antibiotics under a humidified atmosphere of $95 \%$ air and $5 \% \mathrm{CO}_{2}$. Every third day the medium was doubled, and every six th day cells were centrifuged and suspended $(1: 4)$ in the fresh medium. The experiments were carried out on U937 cells differentiated into a macrophage-like cells in the presence of PMA at a concentration of $34 \mathrm{ng} / \mathrm{ml}$ for $48 \mathrm{~h}$. During that period viable and differentiated cells adhered to the culture plates. Unattached cells were discarded and tested factors (in RPMI with $2 \% \mathrm{FBS}$ ) added after additional $24 \mathrm{~h}$ culturing of the adherent cells without PMA. Cells were cultured in 12-well plates (Costar) $\left(10^{6}\right.$ cells per well) for cytokine estimation by EUSA, in $90 \mathrm{~mm}$ Petri dishes $(7 \times$ $10^{6}$ cells per dish) for mRNA isolation and in $60 \mathrm{~mm}$ Petri dishes $\left(3 \times 10^{6}\right.$ cells per dish) for isolation of nuclear proteins.

\section{Cytokine assay}

In order to avoid discrepancies related to cytokine secretion, total (medium + cells) TNF $\alpha$, IL-1 $\beta$ and IL-6 proteins were determined using commercially available EUSA kits (Genzyme). After $24 \mathrm{~h}$ of culture with the tested factors, U937 cells were scraped from the wells directly into the medium, subjected to three cycles of freezing and thawing, and centrifuged $(10000 \mathrm{~g}$ for $3 \mathrm{~min}$ ) before cytokine determination.

\section{Isolation of RNA and Northern blot analysis}

Total U937 RNA was extracted using the phenol extraction method and $\mathrm{LiCl}$ precipitation as described by Rose-John et al. ${ }^{15}$ from the cells treated with $10 \mu \mathrm{M}$ RTA for $1 \mathrm{~h}$ followed by 2 or $18 \mathrm{~h}$ incubation with $500 \mathrm{ng} / \mathrm{ml}$ LPS up to the moment of RNA extraction. RNA samples $(5 \mu \mathrm{g})$ were separated by electrophoresis in $1 \%$ agarose gel under denaturing conditions. ${ }^{16}$ RNA was then transferred to Hybond-N membranes (Amersham, Arlington, IL) according to the manufacturer's instructions. Hybridization with ${ }^{32}$ Plabelled probes was performed overnight at $65^{\circ} \mathrm{C}$ in a mixture containing $1.0 \mathrm{M} \mathrm{NaCl}, 1 \% \mathrm{SDS}$ and $10 \%$ dextran sulphate. Specific mRNAs were detected using the following probes : $1.1 \mathrm{~kb}$ Pst I-Pst $\mathrm{I}$ restriction fragment of human TNFa cDNA (ATCC, Rockville, MA), $1.2 \mathrm{~kb}$ EcoRI-HindIII fragment of human IL6 cDNA (a generous gift of Dr T. Kishimoto), pGEMI containing a $570 \mathrm{bp}$ SstI-PvuII cDNA fragment of human IL-1 $\beta$ (kindly provided by Immunex ${ }^{\mathrm{TM}}$, Seattle, WA), a cDNA probe specific for the human glyceraldehyde 3-phosphate dehydrogenase (GAPDH) (ATCC, GenBank/EMBL: M17851), and a $1.5 \mathrm{~kb}$ PstIPstI fragment of the pSP64 coding for rat $\beta$-actin (kindly provided by Dr J. Sipe, Boston, USA). The probes were labelled with Megaprime Labeling Kit (Amersham). As the reference, $18 \mathrm{~S}$ and $28 \mathrm{~S}$ rRNA were visualized in UV light after ethidium bromide staining, or $18 \mathrm{~S}$ rRNA determined by hybridization with the EcoRI-SalI fragment of the plasmid containing human $18 \mathrm{~S}$ rRNA cDNA (kindly provided by $\mathrm{N}$. Bhow nick, Athens, GA). Non-specifically bound radioactivity was removed by washing and the blots were subjected to autoradiography at $-70^{\circ} \mathrm{C}$ using intensifying screens. The relative intensity of the bands was evaluated by densitometry using a computer imaging (MCID) system (Imaging Research Inc., Canada).

\section{Nuclear protein extraction}

Nuclear proteins were obtained by the mini extraction procedure described by Suzuki et al. ${ }^{17}$ PMAprimed U937 cells were cultured for $1 \mathrm{~h}$ with $10 \mu \mathrm{M}$ RTA followed by exposure to $500 \mathrm{ng} / \mathrm{ml}$ of LPS up to the moment of cell collection. Cells were collected with a rubber policeman, washed twice with cold PBS and centrifuged for $5 \mathrm{~min}$ at $400 \times \mathrm{g}$. The cells, suspended in buffer containing $10 \mathrm{mM}$ HEPES ( $\mathrm{pH}$ 7.8), $10 \mathrm{mM} \mathrm{KCl}, 2 \mathrm{mM} \mathrm{MgCl}_{2}, 1 \mathrm{mM}$ DTT, $0.1 \mathrm{mM}$ EDTA, and 0.1 mM PMSF, were incubated on ice for 15 min. Nonidet P 40 was added and samples were centrifuged for $30 s$ at 14000 r.p.m. Pelleted nuclei were resuspended in buffer containing 50 mMHEPES, $50 \mathrm{mM} \mathrm{KCl}, 300 \mathrm{mM} \mathrm{NaCl}, 0.1 \mathrm{mM}$ EDTA, $1 \mathrm{mM}$ DTT and $0.1 \mathrm{mM}$ PMSF, centrifuged for $5 \mathrm{~min}$ at 14000 r.p.m. at $4^{\circ} \mathrm{C}$ and the supernatant was frozen in $10 \%$ glycerol. The protein concentration was determined by Lowry's method.

\section{EMSA}

The following double-stranded oligonucleotides were used for DNA electrophoretic mobility shift assay: the oligonucleotide that contained two binding sites for $\mathrm{NF}-\mathrm{KB}$ from c-myc oncogene corresponding to bp -1101-1081 (5'-AAGTCCGGGTTTTCCCCAACC-3' $)^{18}$ and AP-1 oligonucleotide: 5'-TCGACTAGTATGAGTCAGCCG-3'. ${ }^{19}$ These oligonucleotide probes were either end-labelled with $\left[\gamma_{-}{ }^{32} \mathrm{P}\right] \mathrm{ATP}$ and T4 polynucleotide kinase $(\mathrm{NF}-\mathrm{B})$ or labelled with $\left[\alpha_{-}{ }^{32} \mathrm{P}\right] \mathrm{dCTP}$ and Klenow polymerase (AP-1) (Megaprime Labeling Kit). For gel shift analysis $5 \mu \mathrm{g}$ of nuclear proteins were incubated with $0.5 \mathrm{ng}$ $\left(\mathrm{c} .10^{5} \mathrm{cpm}\right)$ of labelled oligonucleotides. As competitors, a 100 -fold excess of the unlabeled oligonucleotide was added to the binding reaction. 
Table 1. Total concentrations (supernatants + cell lysates) of cytokines $(\mathrm{ng} / \mathrm{ml})$ in U937 cells after $24 \mathrm{~h}$ of culture with RTA $(10 \mu \mathrm{M})$ or LPS $(500 \mathrm{ng} / \mathrm{ml})$, or RTA and LPS. All cells were primed with PMA as described in Materials and Methods. Mean of four to five experiments; \pm SD. The statistical differences were evaluated by paired Student's $t$ test in pairs: control vs RTA*, or control vs LPS ${ }^{* *}$, or LPS vs LPS+RTA***. NS, not significant $(P, 0.05)$

\begin{tabular}{lccc}
\hline & TNF $\alpha$ & $\mathrm{IL}-1 \beta$ & $\mathrm{IL}-6$ \\
\hline Control & $12.11 \pm 2.49$ & $17.10 \pm 5.38$ & $7.57 \pm 3.00$ \\
& $P<0.05^{*}$ & $P<0.05^{*}$ & $P<0.01^{*}$ \\
RTA & $9.23 \pm 2.72$ & $13.87 \pm 5.54$ & $5.37 \pm 1.35$ \\
LPS & $15.75 \pm 3.92$ & $23.24 \pm 5.42$ & $14.53 \pm 5.63$ \\
& $P<0.01^{* *}$ & $P<0.02^{* *}$ & $P<0.02^{* *}$ \\
LPS + RTA & $11.73 \pm 1.72$ & $18.75 \pm 7.60$ & $10.57 \pm 3.46$ \\
& $P<0.02^{* * *}$ & NS & $P<0.05^{* * *}$ \\
& & &
\end{tabular}

\section{Results}

Rooperol tetraacetate inhibition of cytokine mRNAs in PMA-primed U937 cells cultured in the presence and absence of LPS

We found previously that LPS-induced synthesis of TNF $\alpha$, IL-1 $\beta$ and IL-6 proteins was inhibited in human and rat alveolar macrophages, human blood monocytes/macrophages and U937 cells exposed to rooperol and its acetate esters. ${ }^{12}$ This has been confirmed and extended by the data shown in Table 1. The inhibitory effect of rooperol is less pronounced than in blood monocytes ${ }^{12}$ because 'control' U937 cells are in fact significantly stimulated by PMA.

Since cytokine gene expression is often regulated at the pretranslational stages ${ }^{1,4,5}$ we determined the levels of specific mRNAs in U937 cells primed with PMA and stimulated with LPS. To compare early and late responses, measurements of the cytokine mRNAs were carried out at 2 and $18 \mathrm{~h}$ after exposure to LPS. Figure 1A shows that control cells express TNF $\alpha$ mRNA, due to stimulation with PMA, whereas unprimed and unattached cells do not produce cytokines even after stimulation with LPS (Fig. 1B and Ref. 20). As expected, stimulation with LPS increased the abundance of TNF mRNA, especially after $2 \mathrm{~h}$. We also found that pretreatment of cells with RTA decreased levels of TNF $\alpha$ mRNA both in control and LPS-stimulated cells (Fig. 1A and B). Similar pictures were obtained in three consecutive experiments. Exposure of U937 cells to RTA also decreased the amounts of IL-1 $\beta$ and IL- 6 mRNAs, but the effects were more pronounced after $18 \mathrm{~h}$ culture with LPS or/and RTA (Figs 2 and 3). Six independent experiments were carried out and Figs 2 and 3 show typical results. The inhibitory activity of RTA appears to be rather specific for cytokine mRNAs since the amount of 18 S RNA was unaffected both in the presence and absence of LPS. Moreover, RTA at $10 \mu \mathrm{M}$ concentration had no significant effect on the expression of

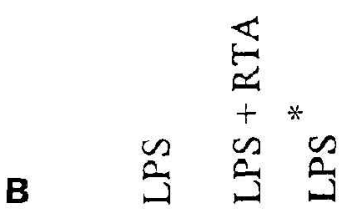

A

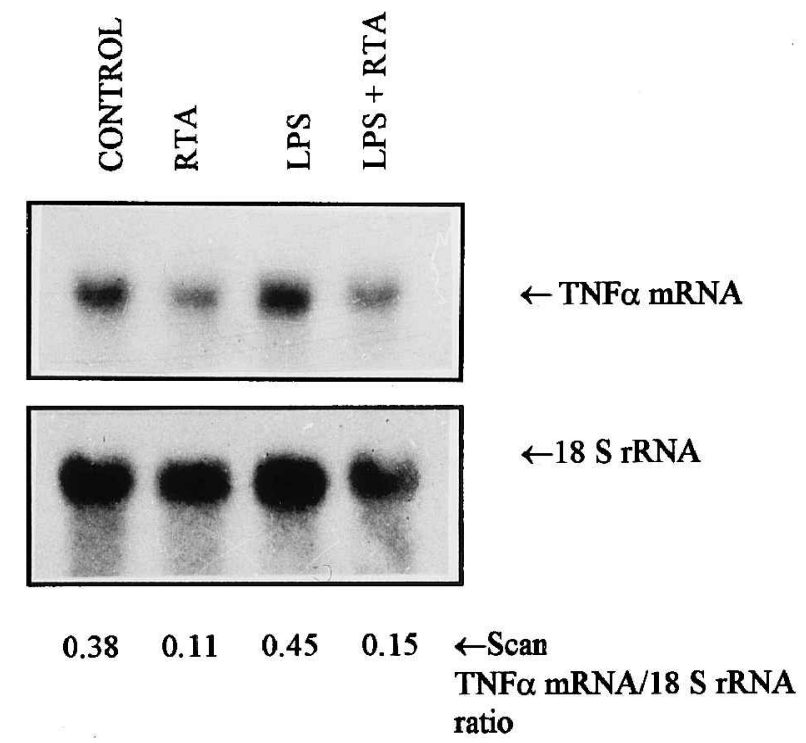

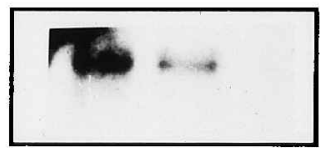

$\leftarrow$ TNF $\propto$ mRNA

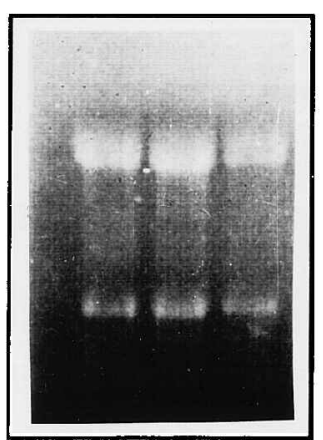

$28 \mathrm{~S}$ rRNA

$18 \mathrm{~S}$ rRNA

$\begin{array}{lll}1 & 2 & 3\end{array}$

FIG. 1. (A and B) Effect of RTA $(10 \mu \mathrm{M})$ and/or LPS $(500 \mathrm{ng} / \mathrm{ml})$ on relative TNF $\alpha$ mRNA abundance in unprimed* $(\mathrm{B}$, lane 3$)$ U937 cells or in the cells primed for $48 \mathrm{~h}$ with PMA $(34 \mathrm{ng} / \mathrm{ml})$ and exposed for $1 \mathrm{~h}$ to RTA and for the next $2 \mathrm{~h}$ to LPS. For comparison blots were rehybridized with a probe for 18 S RNA (A) or UV picture of 18S and 28S rRNA in the ethidium bromide-stained gel is shown (B). For further detail see Materials and Methods. In order to account for differences in RNA load of the gel the ratios of densitometric scans of TNF- $\alpha$ mRNA to $18 \mathrm{~S}$ rRNA are reported (A). 


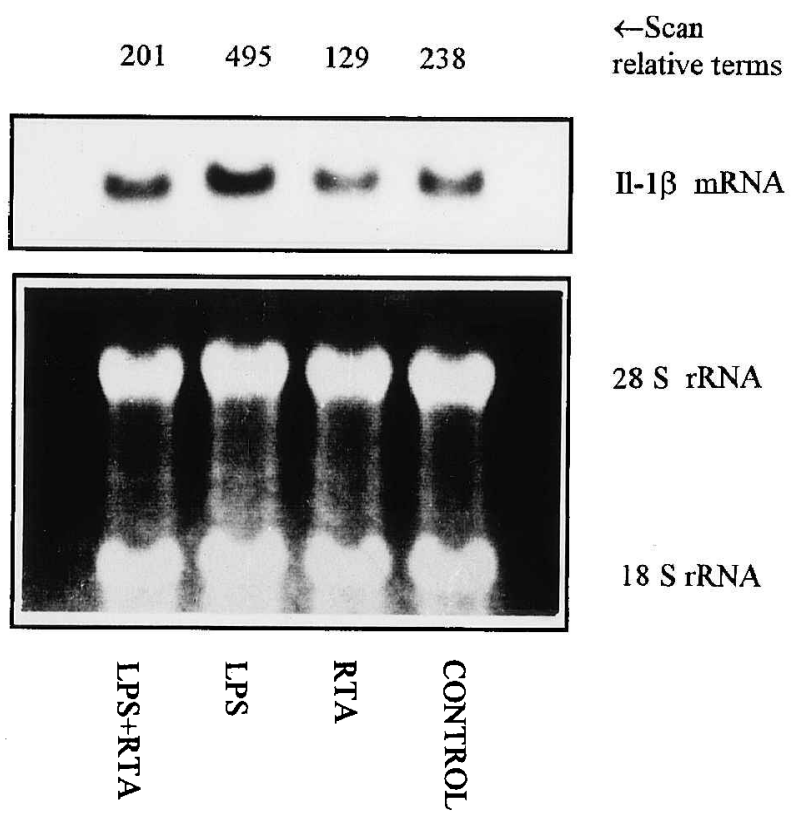

FIG. 2. The effect of RTA $(10 \mu \mathrm{M})$ and/or LPS $(500 \mathrm{ng} / \mathrm{ml})$ on IL$1 \beta$ mRNA abundance in PMA-primed U937 cells after $18 \mathrm{~h}$ incubation with LPS and/or with RTA (cf. Fig. 1). For comparison, the UV picture of $18 \mathrm{~S}$ and $28 \mathrm{~S}$ rRNA in the ethidium bromide-stained gel is shown. Densitometric scans of IL-1 mRNA are expressed in arbitrary units.

$\beta$-actin (a typical structural protein of the cell) and GAPDH (one of the glycolytic pathway enzymes) (Fig. 4). These results suggest that RTA inhibits the synthesis of inflammatory cytokines at the transcriptional level. As shown recently by several authors, translation of cytokine mRNA requires an additional signal provided by stress-responsive kinases and thus in certain cases a dissociation of transcription from translation may occur. ${ }^{4,21}$ Our results presented in Table 1 indicate that changes in the total cytokine
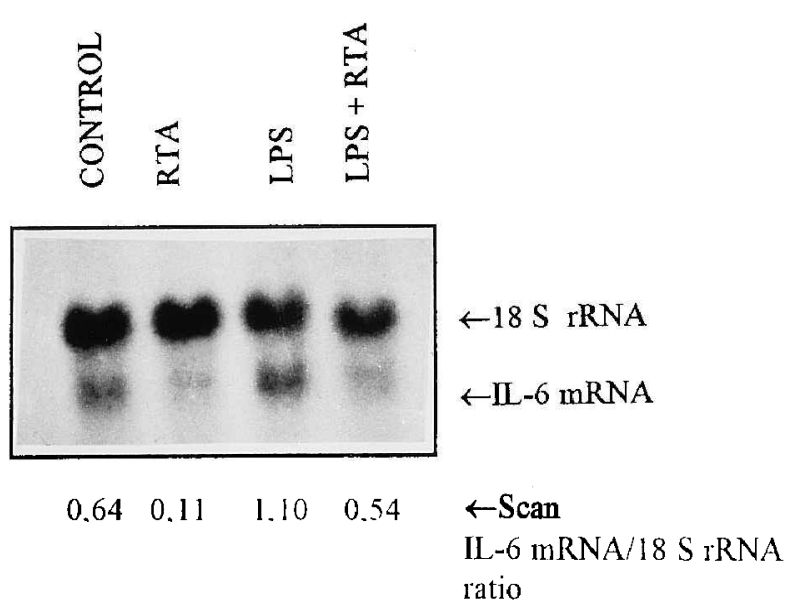

FIG. 3. Effect of RTA $(10 \mu \mathrm{M})$ and/or LPS $(500 \mathrm{ng} / \mathrm{ml})$ on IL-6 mRNA abundance in PMA-primed U937 cells after $18 \mathrm{~h}$ incubation (cf. Fig. 2). For comparison, the hybridization pattern of $18 \mathrm{~S}$ rRNA is shown. The ratios of densitometric scans of IL-6 mRNA to18 S rRNA are reported.
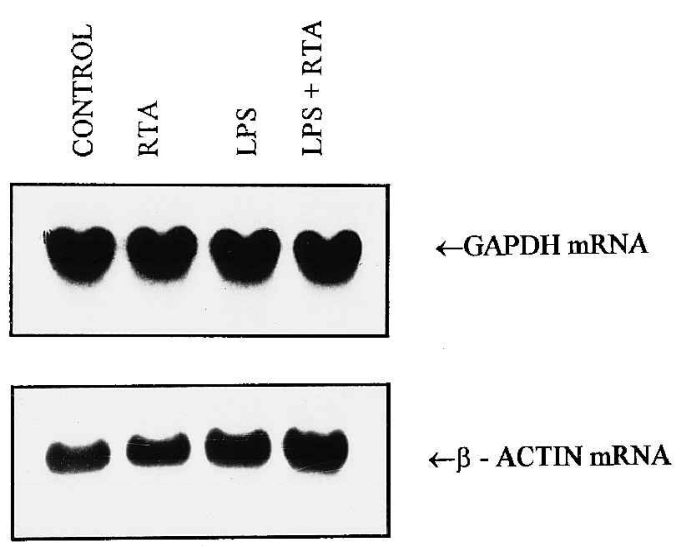

FIG. 4. Abundance of GAPDH mRNA and $\beta$-actin mRNA in PMA-primed U937 cells cultured for $18 \mathrm{~h}$ with RTA $(10 \mu \mathrm{M})$ and/or LPS $(500 \mathrm{ng} / \mathrm{ml})$.

contents (cell + media) elicited by LPS and RTA in U937 cells roughly correspond to changes in the amount of the specific mRNAs (Figs 1-3), which is consistent with a pretranslational site of action of RTA.

\section{Inhibition of binding activity of transcription factors NF- $\mathrm{B}$ B and AP-1 by RTA in PMA-primed U937 cells cultured in the presence and absence of LPS}

Cytokine gene promoters contain multiple regulatory elements recognized by several transcription factors, the most important being NF- $\mathrm{B}, \mathrm{AP}-1$ and C/EBP. ${ }^{4,5,22}$ It is known that in U937 cells both PMA and LPS activate $\mathrm{NF}-\mathrm{BB}^{23-25}$ Figure $5 \mathrm{~A}$ shows that RTA decreased NF- $\mathrm{B}$ binding activity in PMA-primed (control) and LPS-stimulated U937 cells $30 \mathrm{~min}$. following exposure to LPS. At shorter (15 min) (Fig. $5 \mathrm{~B})$ or longer than $4 \mathrm{~h}$ incubation times the effect of RTA was less pronounced (data not shown). The inhibitory effect of RTA was comparable in control (PMA-primed) and LPS-stimulated cells (Fig. 5A). When nuclear extracts from U937 cells were analysed by EMSA (three independent experiments) with the AP-1 probe inhibition of binding by RTA was observed after $30 \mathrm{~min}$ and after $1 \mathrm{~h}$ exposure to LPS (Fig. 6).

\section{Discussion}

The U937 cell line, primed toward macrophage differentiation with PMA, is a useful model for studying the regulation of cytokine synthesis. ${ }^{17,24,25}$ Although PMA affects protein kinase $\mathrm{C}$ and induces synthesis of cytokines (high 'control' values), thereby reducing the relative response to LPS, the U937 cells represent a uniform population that can be easily cultured in amounts sufficient for analysis of RNA and nuclear proteins. Using this model we demonstrated that RTA in $10 \mu \mathrm{M}$ concentration, which does not 
A

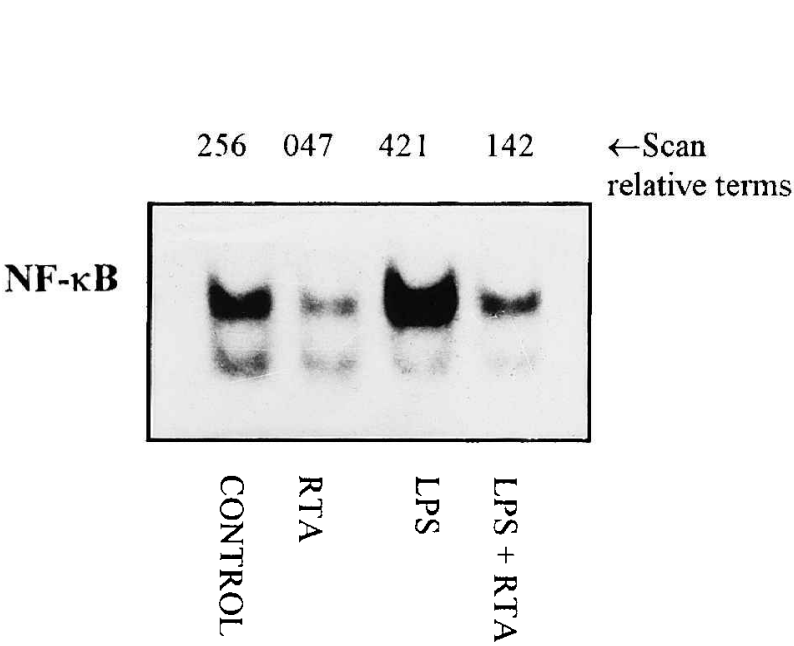

B

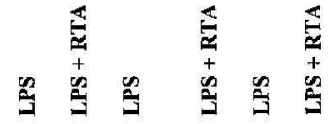

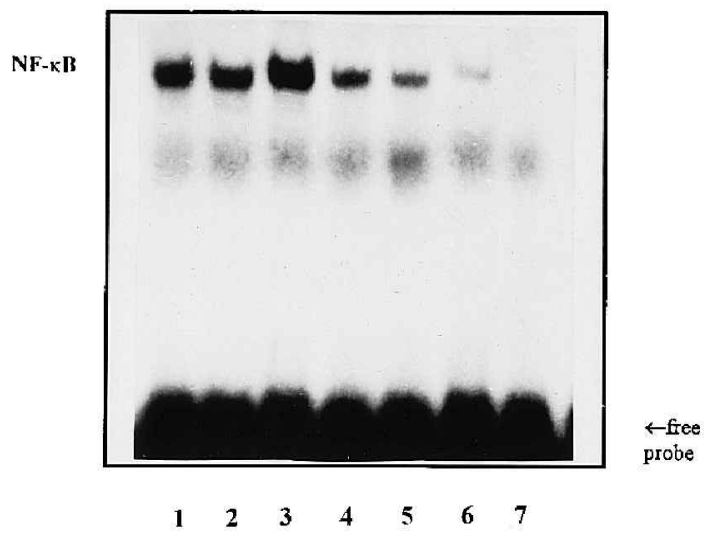

FIG. 5. (A and B) Inhibition by RTA of NF-кB binding to DNA sequences. Electrophoretic mobility shift assay of nuclear extracts isolated from (A) control, RTA- $(10 \mu \mathrm{M})$, LPS- $(500 \mathrm{ng} / \mathrm{ml})$ or RTA + LPS-treated U937 cells primed with PMA; (B) LPS- (500 ng/ml) or LPS+RTA $(10 \mu \mathrm{M})$ - treated U937 cells primed with PMA. Cells were incubated for $1 \mathrm{~h}$ with RTA, followed by LPS addition (A) for $30 \mathrm{~min}$ or (B) for $15 \mathrm{~min}$, lanes 1,2; $45 \mathrm{~min}$, lanes 3,4; and $90 \mathrm{~min}$, lanes 5,6. In lane 7 competitor (unlabelled oligo DNA) was run. The nuclear extracts were isolated and processed as described in Materials and Methods. Densitometric scans (A) are expressed in arbitrary units.

show detectable cytotoxic effects such as inhibition of total protein synthesis or leakage of lactate dehydrogenase, ${ }^{12}$ decreases abundance of mRNAs coding for TNF $\alpha$, IL-1 $\beta$ and IL- 6 both in control (PMAprimed) and LPS-stimulated U937 cells (Figs 1-3). From comparison of scanning values it is evident that the 'inhibitory index' (control vs. RTA, and LPS vs. LPS+ RTA) is very similar suggesting that RTA acts on both PMA-induced and LPS-induced expression of cytokine genes. This may indicate a common target of RTA on the intracellular signalling pathway but the problem requires further studies.

On the other hand, mRNAs coding for other cellular proteins (GAPDH, $\beta$-actin) were not detectably affected by RTA. Thus, it can be concluded that RTA inhibits synthesis of the inflammatory cytokines at the transcriptional level, in contrast to other inhibitors such as bicyclic imidazoles ${ }^{22}$ or piperazine derivatives ${ }^{11}$ which affect translation stages, or tenidap, which acts indirectly by inhibiting the cyclooxygenase pathway. ${ }^{26}$ The observed decreases in the amounts of cytokine mRNAs in the presence of RTA could result from corresponding changes in transcription rates or mRNA stability. Cytokine mRNAs contain adenylate/uridylate-rich elements which are held responsible for the short half life of their messages. ${ }^{27}$ To exclude the possibility that RTA enhances the rate of cytokine mRNA degradation additional experiments with actinomycin D are required.

On the other hand, the results of our experiments point to the interaction of rooperol with transcription factors, known to be required for cytokine gene

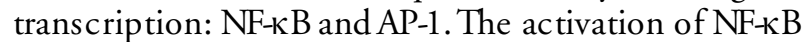

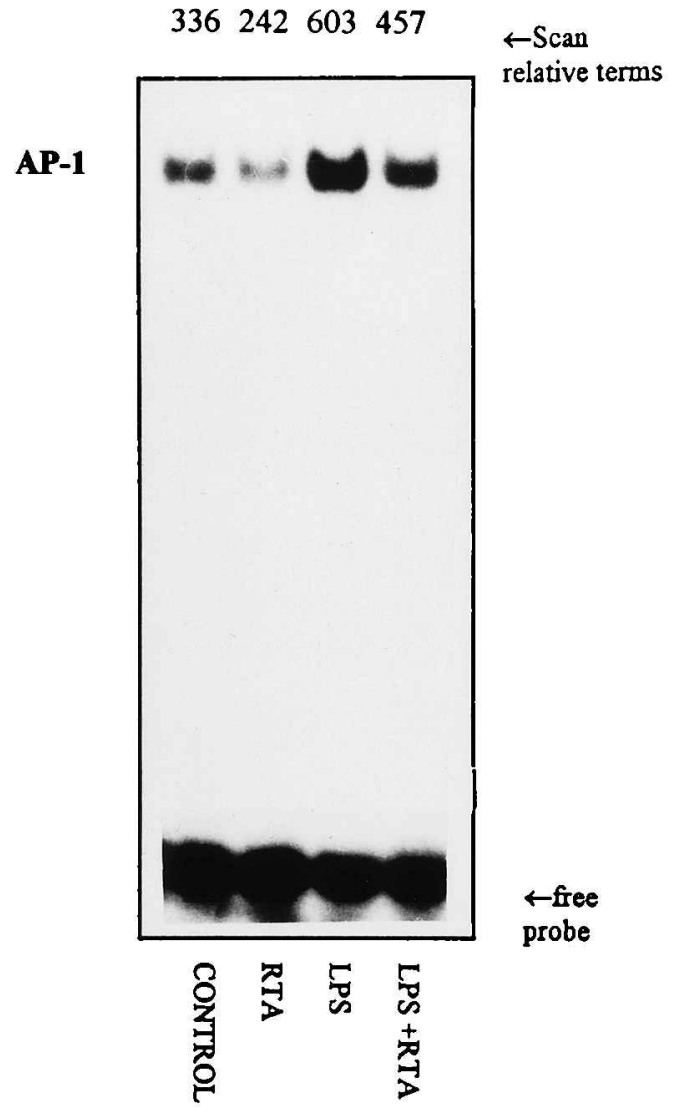

FIG. 6. Inhibition of AP-1 binding to DNA sequences following $60 \mathrm{~min}$ RTA treatment or/and $60 \mathrm{~min}$ exposure to LPS. Electrophoretic mobility shift assay of nuclear extracts isolated from control, RTA- $(10 \mu \mathrm{M})$, LPS- $(500 \mathrm{ng} / \mathrm{ml})$ or LPS+RTA- treated U937 cells primed with PMA. Cells were incubated for $60 \mathrm{~min}$ with RTA, followed by an additional $60 \mathrm{~min}$ with LPS and then nuclear extracts were isolated and processed as described in Materials and Methods. Densitometric scans are expressed in arbitrary units. 
involves an oxidation step with possible involvement of reactive oxygen species ${ }^{17,28}$ and several antioxidants showing anti-inflammatory properties act at this stage. ${ }^{6,28}$ As shown by van der Merwe et al. ${ }^{13}$ rooperol belongs to the group of biologically active antioxidants, and thus by interfering with NF- $\mathrm{B}$ activation may inhibit synthesis of inflammatory cytokines. Redox regulation of the AP-1 transcription factor complex is also well documented in both U937 and HeLa cells ${ }^{24,29}$ and may explain the RTA-elicited reduction of AP-1 binding observed in our experiments (Fig. 6). Since EMSA showed only a transient decrease in the binding capacity of NF- $\kappa \mathrm{B}$ other possible sites of anticytokine action of RTA may be identified in future.

We can conclude, however, that RTA influences abundance of mRNAs coding for TNF $\alpha$, IL-1 $\beta$ and IL-6 in human macrophage-like cells and affects binding of transcription factors implicated in cytokine gene expression. This provides a better understanding of the activity of RTA as potential anti-inflammatory and anticytokine drug.

\section{References}

1. Zhong WW, Burke PA, Hand T, Walsh M, Hughes LA, Forse RA. Regulation of cytokine mRNA expression in lipopolysaccharide-stimulated human macrophages. Arch Surg 1993; 128: 158-164.

2. Cavaillon JM. Cytokines and macrophages. Biomed Pharmacother 1994; 48: $445-453$.

3. Laskin DL, Pendino KJ. Macrophages and inflammatory mediators in tissue injury. Annu Rev Pharmacol Toxicol 1995; 33: 655-677.

4. Dinarello CA. Biologic basis for interleukin-1 in disease. Blood 1996; 87: 2095-2147.

5. Koj A. Initiation of acute phase response and synthesis of cytokines. Biochim Biophys Acta 1996; 1317: 84-94.

6. Allison AC, Lee JC, Eugui EM. Pharmacological regulation of the production of the proinflammatory cytokines TNFa and IL-1 $\beta$. In: Aggarval BB, Puri RK, eds. Human Cytokines: Their Role in Disease and Thera py. Cambridge, MA: Blackwell Science, 1995: 689-713.

7. Breedveld F. Tenidap: a novel cytokine-modulating antirheumatic drug for the treatment of rheumatoid arthritis. Scand J Rheumatol 1994; 2 (Suppl. 100): 31-44.

8. Ounissi-Benkalha H, Pelletir JP, Tardif G, Mineau F, Jolicoeur FC, Ranger P, Martel-Pelletier J. In vitro effects of 2 antirheumatic drugs on the synthesis and expression of proinflammatory cytokines in synovial membranes from patients with rheumatoid arthritis. J Rheumatol 1996; 23: $16-23$.

9. Barnes PJ, Lew FY. Nitric oxide and asthmatic inflammation. Immunol To day 1995; 16: 128-130.

10. Lee JC, Laydon JT, McDonnell PC, Gallagher TF, Kumar S, Green D, McNulty D, Blumenthal MJ, Heyes JR, Landvatter SW, Strickler JE, McLaughlin MM, Siemens IR, Fisher SM, Livi GP, White JR, Adams JL,Young PR.A protein kinase involved in the regulation of inflammatory cytokine biosynthesis. Nature 1994; 372: 739-746.
11. Rordorf-Adam C, Geiger T, Henn R, Arnold J, Solf R, Wiesenberg I, Ferrini PG, Vosbeck K. CGP 47969A: a novel inhibitor of the synthesis of inflammatory cytokines. Agents Actions 1994; 43: 53-59.

12. Guzdek A, Nizankowska E, Allison AC, Kruger PB, Koj A. Cytokine production in human and rat macrophages and dicatechol rooperol and esters. Biochem Pharmacol 1996; 52: 991-998.

13. van der Merwe MJ, Jenkins K, The ron E, Van der Valt BJ. Interaction of the di-catechols rooperol and nordihydroguaiaretic acid with oxidative systems in the human blood. Biochem Pharmacol 1993; 45: 303-311.

14. Bereta J, Bereta M, Allison AC, Kruger PB, Koj A. Inhibitory effect of dicatechol rooperol on VCAM-1 and iNOS expression in cytokinestimulated endothelium. Life Sci 1997; 60: 325-334.

15. Rose-John S, Dietrich S, Marks F. Molecular cloning of mouse protein kinase C (PKC) cDNA from swiss 3T3 fibroblasts. Gene 1988; 74 : 465-471.

16. Sambrook S, Fritsch EF, Maniatis T. In: Molecular Cloning, A Laboratory Manual. Cold Spring Harbor: Cold Spring Laboratory Press, 1989.

17. Suzuki YJ, Mizuno M, Packer L Signal transduction for nuclear factor $-\kappa B$ activation. Proposed location of antioxidant-inhibitable step. J Imm unol 1994; 153: 5008-5015.

18. Duyao MP, Buckler AJ, Sonenshein GE. Interaction of an NF-kB-ike factor with a site upstream of the c-myc promoter. Proc Natl Acad Sci USA 1990; 87: 4727-4731.

19. Angel P, Imagawa M, Chin R, Stein B, Imbra RJ, Rahmsdorf HJ, Jonat C, Herrlich P, Karin M. Phorbol ester-inducible genes contain a common cis element recognized by a TPA-modulated trans-acting factor. Cell 1987; 49: 729-739.

20. Willeaume V, Kruys V, Mijatovic T, Huez G. Tumor necrosis factor-alpha production induced by viruses and by lipopolysaccharides in macrophages: similarities and differences. J Inflamm 1996; 46: 1-12.

21. Lee JC, Young PR. Role of CSBP/p38/RK stress response kinase in LPS and cytokine signaling mechanisms. J Leukocyte Biol 1996; 59: $152-157$.

22. Sehgal PB, Wang L, Rayanade R, Pan H, Margulies L Interleukin-6-type cytokines. Ann NY Acad Sci 1995; 762: 1-14.

23. Takeshita S, Gage JR, Kishimoto T, Vredevoe DL, Martinez-Maza O. Differential regulation of IL- 6 gene transcription and expression by IL-4 and IL-10 human monocytic cell lines. J Immunol 1996; 156: 2591-2598.

24. Lee SW, Ilnicka M. Hydrogen peroxide primes promonocytic U937 cells to produce IL-1ß. Ann. NY Acad Sci 1993; 696: 399-401.

25. Coggswell JP, Godlevski MM, Wisely GB, Clay WC, Leesnitzer LM, Ways JP, Gray JG, NF-אB regulates IL-1 $\beta$ transcription through a consensus NF-KB binding site and a nonconsensus CRE-like site. J Immunol 1994; 153: $712-723$.

26. Moore PF, Larson DL, Otterness IG, We issman A, Kadin SB, Sweeney FJ, Eskra JD, Nagahisa A, Sakakibara M, Carty TJ. Tenidap, a structurally novel drug for the treatment of arthritis: antiinflammatory and analgesic properties. Inflamm Res 1996; 45: 54-61.

27. Chen CYA, Shyu AB. AU-rich elements: characterization and importance in mRNA degradation. Trends Biochem Sci 1995; 20: 465-470.

28. Schreck R, Albermann K, Bauerle PA. Nuclear factor $\kappa B$ : an oxidative stress-responsive transcription factor of eukaryotic cells (a review). Free Rad Res Commun 1992; 17: 221-237.

29. Kick G, Messer G, Goetz A, Plewig G, Kind P. Photodynamic therapy induces expression of interleukin 6 by activation of AP-1 but not NF-KB DNA binding. Cancer Res 1995; 55: 2373-2379.

AKNOWLEDGEMENTS. This work was partly supported by grant No 1227/P05/95/08 from the Committee of Scientific Research (KBN, Warsaw, Poland) to A.K. We are grateful to Dr P. B. Kruger for providing rooperol te tracetate.

\section{Received 25 August 1997;} accepted in revised form 10 October 1997 


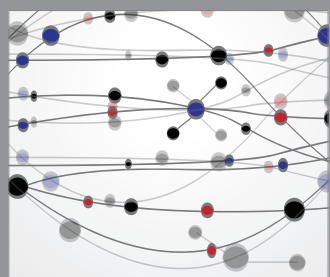

The Scientific World Journal
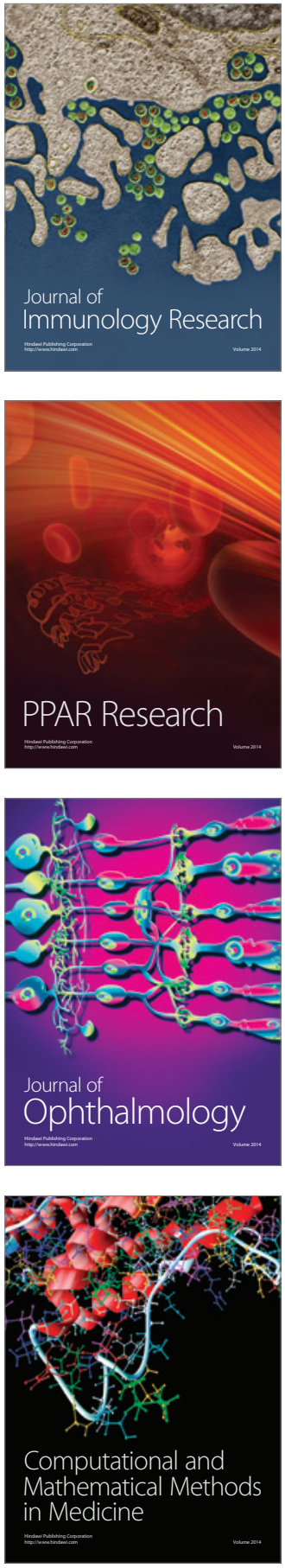

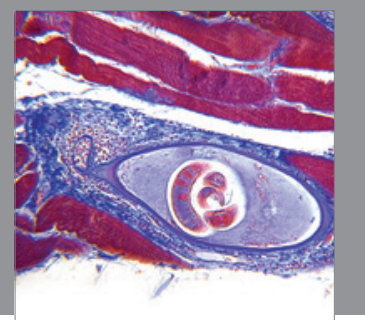

Gastroenterology

Research and Practice
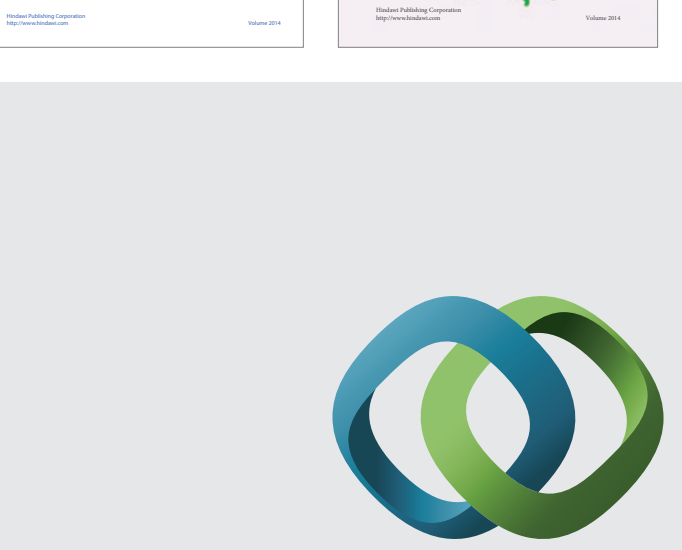

\section{Hindawi}

Submit your manuscripts at

http://www.hindawi.com
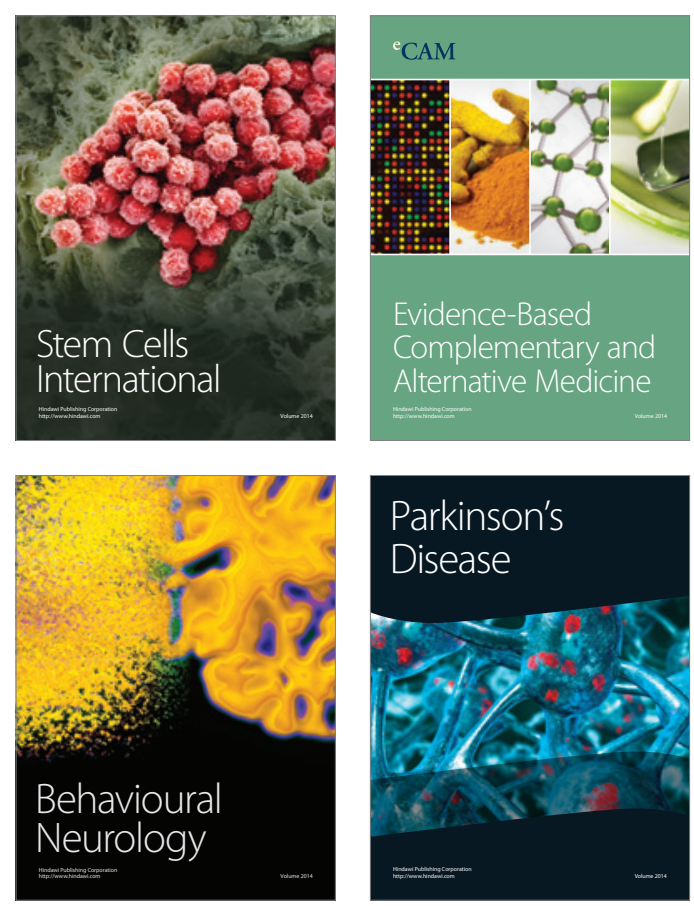

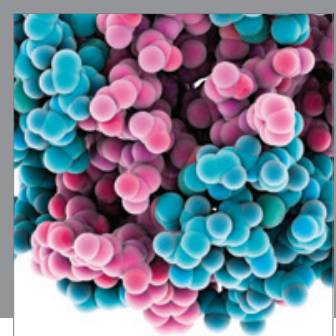

Journal of
Diabetes Research

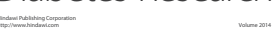

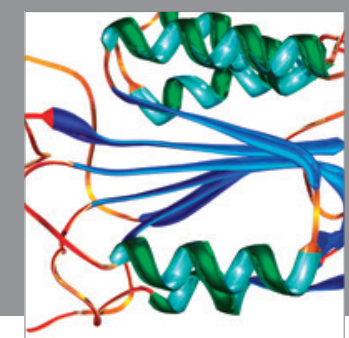

Disease Markers
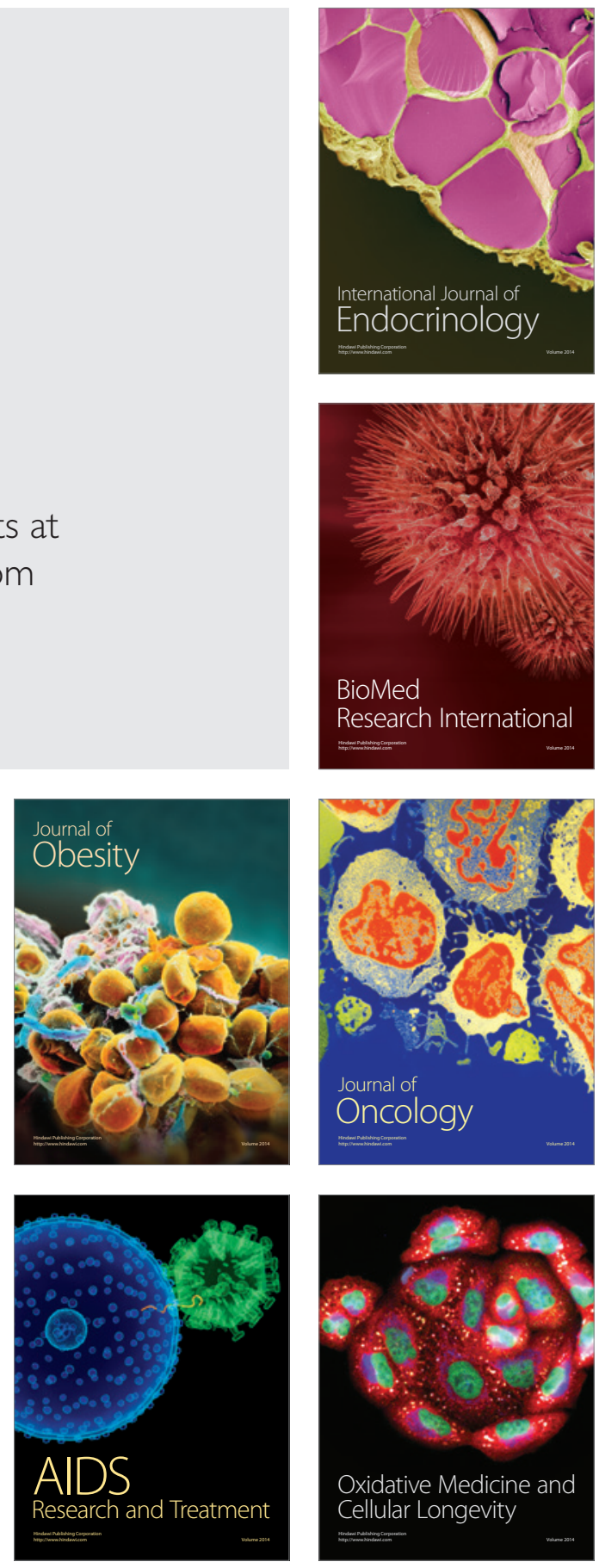